\title{
Microbial Bioremediation of Pesticide Residues: A Review
}

\author{
Sudhansu Bhagawati*, Badal Bhattacharyya, Snigdha Bhattacharjee, \\ E. Bidyarani Devi, Nang Sena Manpoong and Partha Pratim Gyanudoy Das
}

Department of Entomology, Assam Agricultural University, Jorhat (Assam), India

*Corresponding author



\section{Introduction}

India is one of the seven largest countries in the world having an arable land area of 159.7 million hectares. The economy of India is solely based on agriculture and allied sectors and approximately 70 per cent of the population depends on it. India's population is expected to reach 1.6 billion by 2050 , surpassing China in 2025 and in that situation, feeding the whole population will be a great challenge for the country (Wolf et al., 2011).

Moreover due to the pest infestation, approximately 45 per cent of the total food production is reduced or lost annually (Sharma et al., 2016). To conquer the loss of infestation due to various pests and diseases 
as well as to enhance the productivity of crops throughout the world, quantum jumps in the use of synthetic pesticides have now become a part of modern agriculture. Pesticides are organic chemicals purposefully intended for increasing agricultural yield through minimizing the losses of agricultural products caused by crop pests and to control the insect vectors for prevention of the outbreak of human and animal epidemics. In India, the use of pesticides began in 1948 (just after the world war-II) when DDT was imported for the control of malaria and benzene hexachloride (BHC) for locust control (Buyuksonmez et al., 1999). However, pesticide production was started in the country just after the setting up of manufacturing plants of DDT and BHC in 1952. The first report of use of pesticides in agricultural field was started with the advent of Green Revolution which certainly increased the total food production in the country and the globe as well. Of late, 75 per cent of the total pesticides produced in the world are only being used in agricultural practices and over 500 compounds are registered and used worldwide as pesticides or their metabolites (Parte et al., 2017).

Though pesticides plays pivotal role in augmenting food production as well as socioeconomic upliftment of farming community, its large scale and indiscriminate use has created a highly unstable ecosystem by developing insecticide resistance in insects, pest resurgence, elimination of parasites, predators and pollinators etc. Moreover, due to the unplanned application of pesticides, only 10 per cent actually penetrate the target organism and the remaining are deposited as residues on non-target areas such as soil and water causing serious environmental pollution. The unwanted side effects of pesticide residues to humans and other life forms in terms of carcinogenicity, mutagenicity, reproductive disorder, neurological and various other health problems have already been reported by Forget, 1993 and Abhilash and Singh, 2009. Many of the pesticides which were reported to be lethal to both nature and humans were subsequently banned, although there is every possibility that the residues accumulated in the soil or water may enter again at any trophic level of the food chain (Parte et al., 2017). Thus, looking towards the environmental concerns and health hazards resulting due to the continuous use of these noxious pesticides, concerted efforts have already been made to lower down the possible effects of pesticide residues mostly in agricultural field through many physical (photo degradation and high temperature incineration) and chemical (by using powerful transient chemicals) methods (Torres-Duarte et al., 2009). However, both physical and chemical approaches are highly expensive and not eco-friendly in nature and hence the bioremediation approach mostly done by exploring pesticide degrading microorganisms has emerged as an ecofriendly, effective and economical alternative to address the concerned issues (Aislabie and Lloyd-jones, 1995; Ortiz-Hernández et al., 2003 and Singh and Thakur, 2006). Different microorganisms, their enzymes and genes responsible for bioremediation of pesticide residues, challenges and future thrust areas related to the subject have critically reviewed in this paper.

\section{Factors related to pesticide residues degradation}

The amount of pesticides initially laid down after application on any surface is termed as deposit and those deposits after a lapse of time is referred to as pesticide residues (Prasad, 2014). The pesticide residues are subjected to many biotic and abiotic factors after getting deposited into soil or water. Out of the abiotic factors, temperature, humidity, 
$\mathrm{pH}$, water content, organic matter content, viscosity and climate plays an important role in the degradation of residues. High temperature along with high humidity climates, high organic matter and alkaline $\mathrm{pH}$ of the soil generally resulted in a rapid degradation of pesticide residues. Amount of pesticide applied and the molecular structure of the pesticide also depends on the degradability of its residues. There are reports that the degradation of $2,4,5-\mathrm{T}$ is fourteen fold higher as compared to 2,4-D due to the addition of one chlorine atom at the $5^{\text {th }}$ carbon (Ye et al., 2018). However, the degradation of pesticide residues principally depends on the diversity and action of microorganisms.

\section{Potentiality of microorganisms in pesticide residue remediation}

The ability of the soil to reduce the concentration of any contaminants naturally is known as "natural attenuation". The microorganisms occurred in the soil plays an important role in assisting chemical reactions which break down the molecular structures of the contaminants to less toxic molecules. On the other hand, the exploration of such naturally occurring microorganisms by the intervention of humans to break down or degrade toxic chemical compounds accumulated in the environment is known as "Bioremediation". Bioremediation of pesticide residues through microorganisms has been recognized since time immemorial.

Rapid rate of reproduction, high surface area volume ratio and high catalytic power make microorganisms a potential source for bioremediation of pesticide residues. Some species of microbes are even reported to synthesis pesticide degrading enzymes either naturally or through random mutation whereas in some species synthesis of degrading enzymes are induced in the presence of a particular pesticide (Tewari,
2012). Out of all the microorganisms, certain species of bacteria, especially actinomycetes and cyanobacteria, algae and fungi presented in Table 1 are reported to have the pesticide degrading ability.

\section{The three phases of pesticide residue degradation by microorganisms}

The first step of degradation of any contaminants is primarily carried out by fungi in which they biotransform pesticides and other xenobiotics to certain nontoxic products intermediate by changing the original molecular structure. The nontoxic intermediates are then susceptible to further degradation by bacteria (Diez, 2010). Both the fungi and bacteria produces extracellular enzymes such as esterases, glutathione Stransferases (GSTs) and cytochrome P450 which induced breakdown of the pesticide molecules through hydrolysis, oxidation, addition of amino group or hydroxyl group, dehalogenation, reduction of a nitro group to an amino group, replacement of a sulfur with an oxygen molecule, metabolism of side chains, ring cleavage etc. (Bass and Field, 2011).

Degradation of pesticide residues in soil generally undergoes three processes. The parent compounds forms some intermediate molecules which are more water soluble through oxidation, reduction or hydrolysis in the first phase. In the second phase of metabolism, the intermediate molecules conjugated with a sugar or amino acid which makes the final molecule more water soluble and comparatively less toxic. In the final phase, Phase II metabolites are transformed in to a final secondary conjugates with relatively non-toxic molecules. In each of these process, there is an involvement of certain intracellular or extra cellular enzymes like oxidoreductases (mixed function oxidase, cytochrome p450, monooxygenases, dioxygenases etc.), 
transferases (Glutathione S-transferases) and hydrolases (hydrolase, esterase, dehalogenases etc.) which were reported to be synthesized by both the bacteria and fungi (Jauregui et al., 2003, Van Eerd et al., 2003, Singh and Singh, 2005, Joosten et al., 2007, and Pizzul et al., 2009). Lists of different microbial enzymes responsible for the degradation of pesticide residues as reported byScott et al., (2008); Ortiz-Hernandez et al., (2013) and Sharma et al., (2016) are presented in Table 2.

\section{Microbial genes involved in pesticide} residue degradation

Unlike normal environmental conditions, the genes of the microorganisms expressed differently when they are exposed to any stressed situations. Of late, the adoption of microorganisms to altered environment as well as mechanism to degrade contaminants from the soil has already been studied through recent biotechnological tool like genomics, metagenomics, proteomics and bioinformatics (Arora and Bae, 2014).

Expression of genes or a particular protein responsible for the degradation of pesticides through genome sequencing or recombinant DNA technology have also been reported (Widada et al., 2002). The gene responsible for degrading pesticide residues mostly occurs either on chromosomes or plasmids and transposons. Li et al., (2007) identified "opd" gene, a gene having 996 nucleotides responsible for degrading organophosphate pesticides and its residues.

Similarly, "mpd" gene having the ability to degrade methyl parathion has been identified and recorded in Pseudaminobacter sp., Achrobacter sp., Brucella sp., Ochrobactrum sp. and Pleisomonas sp. (Zhongli et al., 2001). Some genes responsible for degrading pesticides and its residues as reported by
Singh and Walker (2006) and OrtizHernandez et al., (2013) are listed in Table 3.

\section{Examples of pesticide residues degraded} through microorganisms

\section{Endosulfan biodegradation}

Endosulfan is an organochlorine insecticide currently banned in almost all the countries. Tow bacterium viz., Mycobacterium tuberculosis and Arthrobacter sp. are reported to degrade the residues of endosulfan in soil. After deposition in the soil, the endosulfan undergoes metabolism to form endosulfan sulphate and endosulfan diol as primary metabolites.

Mycobacterium tuberculosis synthesized ESD enzyme which degrades beta endosulfan to monoaldehyde and hydroxyether and transforms alpha endosulfan to endosulfan sulphate as more toxic compounds. However, monooxygenase enzyme encoded by ese gene in Arthrobacter sp. KW oxidize endosulfan sulphate to endosulfan monoalcohol as relatively less toxic compound to the environment (Weir et al., 2006).

\section{Carbamate biodegradation}

Synthesis of carbofuran hydrolase encoded by "mcd" genes resulted in hydrolysis of the methyl carbamate linkage which leads to the degradation of carbamate pesticides. Tomasek and Karns (1989) first described the gene in Achromobacter sp. Later, the enzyme as well as gene was also reported from an array of bacteria viz., Pseudomonas, Sphingomonas, Arthrobacter, Mesorhizobium, Ralstonia, Rhodococcus, Ochrobactrum, Spingobium, Bosea, Microbacterium and Bacillus (Desaint et al., 2000). Of late, Aspergillus niger has also been reported to degrade carbamate pesticides and its residues (Qing et al., 2006). 


\section{Organophosphorous biodegradation}

The work on organophosphorous pesticide residue degradation started in 1973 when Sethunathan and Yoshida isolated Flavobacterium sp. to degrade diazinon and parathion. This soil bacterium synthesizes organophosphate hydrolase or phosphotriesterase enzymes which are the prime requisite for organophosphate degradation. These enzymes hydrolyze phosphoester bonds, such as $\mathrm{P}-\mathrm{O}$ and the hydrolysis mechanism involves a water molecule at the phosphorus center (OrtizHernández et al., 2003). Some of the bacteria responsible for degrading organophosphorous componds are Flavobacterium sp., Plesimonas sp. strain M6, Pseudomonas moteilli etc. (Ortiz-Hernandez et al., 2013).

\section{Neonecotinoid biodegradation}

Like organophosphorus compounds, the neonicotinoids are also degraded by many bacterial species such as Stenotrophomonas maltophilia CGMCC 1.1788, Pseudomonas sp. $1 \mathrm{G}$, Leifsonia sp. and Rhodotorula mucilaginosa strain IM-2 etc. (Dai et al., 2007 and Pandey et al., 2009)

Table.1 Microorganisms used in the degradation of different pesticide and their residues

\begin{tabular}{|c|c|c|}
\hline Pesticides & Microorganisms & References \\
\hline DDT & $\begin{array}{l}\text { Escherichia coli } \\
\text { Enterobacter aerogenes } \\
\text { E. cloacae } \\
\text { Klebsiella pneumonia } \\
\text { Pseudomonas putida } \\
\text { Bacillus circulans } \\
\text { Hydrogenomonas sp. } \\
\text { Pseudomonas aeruginosa } \\
\text { Micrococcus sp. } \\
\text { Bacillus pumilus } \\
\text { Flavobacterium } \mathrm{sp} \text {. }\end{array}$ & $\begin{array}{c}\text { Ortega et al., } 2011 \\
\text { Fang et al., } 2010 \\
\text { Kamanavalli and Ninnekar, } 2005 \\
\text { Pesce and Wunderlin, } 2004 \\
\text { Patil et al., } 1970 \\
\text { Wedemeyer, } 1967\end{array}$ \\
\hline Endosulfan & $\begin{array}{l}\text { Pseudomonas aeruginosa } \\
\text { Bacillus circulans } \\
\text { Flavobacterium } \mathrm{sp} .\end{array}$ & Bhalerao and Puranik, 2007 \\
\hline Lindane & $\begin{array}{l}\text { Bosea thiooxidans } \\
\text { Sphingomonas paucimobilis } \\
\text { Streptomyces sp. } \\
\text { Pleurotus ostreatus }\end{array}$ & $\begin{array}{l}\text { Benimeli et al., } 2008 \\
\text { Rigas et al., } 2005\end{array}$ \\
\hline Aldrin and Endrin & $\begin{array}{l}\text { Trichoderma viridae } \\
\text { Pseudomonas sp. } \\
\text { Micrococcus sp. } \\
\text { Bacillus sp. } \\
\text { Arthrobacter sp. }\end{array}$ & Patil et al., 1970 \\
\hline Toxaphene & Bjerkandera sp. & Patil et al., 1970 \\
\hline Dieldrin & Pseudomonas aeruginosa & Matsumura et al., 1968 \\
\hline PCP & $\begin{array}{l}\text { Arthrobacter sp. } \\
\text { Flavobacterium sp. }\end{array}$ & $\begin{array}{c}\text { Crawford and Mohn, } 1985 \\
\text { Stanlake and Finn, } 1982\end{array}$ \\
\hline
\end{tabular}




\begin{tabular}{|c|c|c|}
\hline Heptachlor & $\begin{array}{l}\text { Phanerochaete chrysosporium } \\
\text { Phlebia sp. }\end{array}$ & $\begin{array}{l}\text { Xiao et al., } 2010 \\
\text { Arisoy and Kolankaya, } 1998\end{array}$ \\
\hline Cypermethrin & $\begin{array}{l}\text { Escherichia coli } \\
\text { Staphylococcus aureus } \\
\text { Pseudomonas aeruginosa } \\
\text { P. Stutzeri } \\
\text { Bacillus subtilis } \\
\text { Enterobacter asuburiae }\end{array}$ & Pankaj et al., 2016 \\
\hline Lambda-cyhalothrin & $\begin{array}{l}\text { Klebsiella } \text { sp. } \\
\text { Pseudomonas oleovorans }\end{array}$ & Chen et al., 2015 \\
\hline Carbofuran & $\begin{array}{l}\text { Pseudomonas sp. } \\
\text { Flavobacterium } \mathrm{sp} . \\
\text { Achromobacterium } \mathrm{sp} . \\
\text { Sphingomonas } \mathrm{sp} . \\
\text { Arthrobacter } \mathrm{sp} .\end{array}$ & Head et al., 1992 \\
\hline Chlorpyriphos & $\begin{array}{l}\text { Sphingomonas sp. } \\
\text { Enterobacter sp. }\end{array}$ & $\begin{array}{l}\text { Li et al., } 2007 \\
\text { Singh et al., } 2004\end{array}$ \\
\hline $\begin{array}{l}\text { Dimetoate and } \\
\text { Malathion }\end{array}$ & $\begin{array}{l}\text { Pseudomonas } \\
\text { frederiksbergensis }\end{array}$ & Al-Qurainy and Megeed, 2009 \\
\hline Methyl parathion & Sphingobium sp. & Yuanfan et al., 2010 \\
\hline Diazinon & $\begin{array}{l}\text { Serratia liquefaciens } \\
\text { S. marcescens } \\
\text { Pseudomonas } \mathrm{sp} .\end{array}$ & Cycon et al., 2009 \\
\hline Prophenofos & $\begin{array}{l}\text { Pseudomonas putida } \\
\text { Burkholderia gladioli }\end{array}$ & Malghani et al., 2009 \\
\hline Atrazine and Alachlor & $\begin{array}{l}\text { Arthrobacter } \mathrm{sp} . \\
\text { Clavibacter } \mathrm{sp} . \\
\text { Nocardia } \mathrm{sp} . \\
\text { Rhodococcus } \mathrm{sp} . \\
\text { Nocardioides } \mathrm{sp} . \\
\text { Streptomyces } \mathrm{sp} .\end{array}$ & Behki et al., 1993 \\
\hline 2,4-D & Ralstonia eutropha & Chung and Ka, 1998 \\
\hline Propiconazole & Pseudomonas putida & Sarkar et al., 2009 \\
\hline Carbendazin & Pseudomonas aeruginosa & Tian and Chen, 2012 \\
\hline Pentachloronitrobenzene & $\begin{array}{l}\text { Rhizoctonia solani } \\
\text { Botrytis } \mathrm{sp} . \\
\text { Aspergillus } \mathrm{sp} . \\
\text { Penicillium } \mathrm{sp} . \\
\text { Fusarium } \mathrm{sp} . \\
\text { Sclerotinia } \mathrm{sp} . \\
\text { Tilletia caries }\end{array}$ & $\begin{array}{c}\text { Pesce and Wunderlin, } 2004 \\
\text { Spain and Nishino, } 1987\end{array}$ \\
\hline Iprodione & Pseudomonas aeruginosa & Bending and Rodríguez, 2007 \\
\hline
\end{tabular}


Table.2 Microbial enzymes reported for degradation of pesticide residues

\begin{tabular}{|c|c|c|}
\hline Enzyme & $\begin{array}{l}\text { Microorganism responsible for } \\
\text { synthesis }\end{array}$ & Pesticide residues \\
\hline Oxidoreductases (Gox) & $\begin{array}{c}\text { Pseudomonas sp. LBr } \\
\text { Agrobacterium sp. strain T10 }\end{array}$ & Glyphosate \\
\hline \multicolumn{3}{|l|}{ Monooxygenases: } \\
\hline ESd & Mycobacterium sp. & Endosulphan \\
\hline Ese & Arthrobacter sp. & $\begin{array}{l}\text { Endosulphan, Aldrin, Malation } \\
\text { and DDT }\end{array}$ \\
\hline Сур76В1 & Helianthus tuberosus & $\begin{array}{l}\text { Linuron, Chlortoluron and } \\
\text { Isoproturon }\end{array}$ \\
\hline $\mathrm{P} 450$ & Pseudomonas putida & $\begin{array}{l}\text { Hexachlorobenzene and } \\
\text { Pentachlorobenzene }\end{array}$ \\
\hline \multicolumn{3}{|l|}{ Dioxygenases } \\
\hline TOD & Pseudomonas putida & Trifluralin \\
\hline E3 & Lucilia cuprina & $\begin{array}{l}\text { Synthetic pyrethroids and } \\
\text { insecticides phosphotriester }\end{array}$ \\
\hline $\begin{array}{l}\text { Phosphotriesterases: } \\
\text { OPH/OpdA }\end{array}$ & $\begin{array}{l}\text { Agrobacterium radiobacter } \\
\text { Pseudomonas diminuta } \\
\text { Flavobacterium sp. }\end{array}$ & Insecticides phosphotriester \\
\hline \multicolumn{3}{|c|}{ Haloalkane Dehalogenases: } \\
\hline LinB & $\begin{array}{l}\text { Sphingobium sp. } \\
\text { Shingomonas sp. }\end{array}$ & $\begin{array}{l}\text { Hexachlorocyclohexane } \\
\text { ( } \beta \text { and } \delta \text { isomers) }\end{array}$ \\
\hline AtzA & Pseudomonas sp. & chloro-s-trazina \\
\hline TrzN & Nocardioides sp. & chloro-s-trazina \\
\hline LinA & $\begin{array}{l}\text { Sphingobium sp. } \\
\text { Shingomonas sp. }\end{array}$ & $\begin{array}{l}\text { Hexachlorocyclohexane } \\
\text { ( } \gamma \text { isomers })\end{array}$ \\
\hline TfdA & Ralstonia eutropha & $2,4-\mathrm{D}$ and pyridyl-oxyacetic \\
\hline DMO & Pseudomonas maltophilia & Dicamba \\
\hline
\end{tabular}

Table.3 Microbial genes responsible for the degradation of pesticide residues

\begin{tabular}{|c|c|}
\hline Gene & Source \\
\hline \multicolumn{2}{|l|}{ Bacterial gene } \\
\hline opdA & Agrobacterium radiobacter \\
\hline Opd & Pseudomonas diminuta \\
\hline adpB & Nocardia sp. \\
\hline $\mathrm{Phn}$ & Bacillus cereus \\
\hline ophB & Burkholderia sp. JBA3 \\
\hline $\operatorname{Imh}$ & Arthrobacter sp. scl-2 \\
\hline Mpd & Ochrobactrum sp. Yw28 and Rhizobium radiobacter \\
\hline opdE & Enterobacter sp. \\
\hline \multicolumn{2}{|l|}{ Fungal genes } \\
\hline A-opd & Aspergillus niger \\
\hline P-opd & Penicillium lilacinum \\
\hline
\end{tabular}


Synthetic chemicals has significantly increased the farmer's economy by saving food loss and also saved the millions of lives by managing pests of public health importance. However, due to the injudicious, indiscriminate and unplanned application of pesticides has certainly affected the ecosystem and its allied services. In many cases, very less per cent of applied pesticides could actually reach the targeted organisms and rest remain deposited as residues in various surfaces causing serious problems to the environment.

Being an eco-friendly and cost effective tool, microorganisms can be explored extensively to address the issue. However, lack of pesticide residue specific microorganisms, less adaptation of microorganisms to the changing environment and lack of formulated pesticide degrading formulated marketable products stands as key bottlenecks of the subject. Selection of appropriate potential strains and their further improvement through genetic engineering to development of a formulated pesticide degrading microbial consortia along with standard method of application may pave the way for the wide applicability of such microbes.

\section{References}

Abhilash, P. C. and Singh, N. 2009. Pesticide use and application: an Indian scenario. J. Hazardous Materials, 165 (13): 1-12.

Aislabie, J. and Lloyd-jones, G. 1995. A review of bacterial degradation of pesticides. Australian J. Soil Res., 33: 925942.

Al-Qurainy, F. and Abdel-Megeed, A. 2009. Phytoremediation and detoxification of two organophosphorous pesticides residues in Riyadh area. World Appl. Sci. J., 6(7): 987-998.

Arisoy, M. and Kolankaya, N. 1998. Biodegradation of heptachlor by
Phanerochaete chrysosporium ME 446: The toxic effects of heptachlor and its metabolites on mice. Turk. J. Biol., 22: 427-434.

Arora, P. K. and Bae, H. 2014. Bacterial degradation of chlorophenols and their derivatives. Microbial Cell Factories, 13 (1): 1-17.

Bass, C. and Field, L. M. 2011. Gene amplification and insecticide resistance. Pest Management Sci., 67 (8): 886-890.

Behki, R., Topp, E., Dick, W. and Germon, P. 1993. Metabolism of the herbicide atrazine by Rhodococcus strains. App. Environ. Microbiol., 59 (6):1955-1959.

Bending, G. D. and Rodriguez-Cruz, M. S. 2007. Microbial aspects of the interaction between soil depth and biodegradation of the herbicide isoproturon. Chemosphere, 66: 664-671.

Benimeli, C. S., Fuentes, M. S., Abate, C. M. and Amoroso, M. J. 2008. Bioremediation of lindane contaminated soil by Streptomyces sp. M 7 and its effects on Zea mays growth. Int. Biodeterior. Biodegradation, 61: 233-239.

Bhalerao, T. S. and Puranik, P. R. 2007. Biodegradation of organochlorine pesticide endosulfan by a fungal soil isolate, Aspergillus niger. Int. Biodeterior. Biodegradation, 59 (4): 315-321.

Buyüksönmez, F., Rynk, R., Hess, T. F. and Bechinski, E. 1999. Occurrence, degradation and fate of pesticides during composting, Part I: Composting, pesticides and pesticide degradation. Compost Sci. Utilization, 7 (4): 66-82.

Chen, S., Deng, Y., Chang, C., Lee, J., Cheng, Y., Cui, Z., Zhou, J., He, F., Hu, M. and Zhang, L. H. 2015. Pathway and kinetics of cyhalothrin biodegradation by Bacillus thuringiensis strain ZS-19. Scientific Rep., 5: 8784.

Chung, J. M. and Ka, J. O. 1998. Isolation and characterization of 2,4dichlorophenoxyacetic acid degrading 
bacteria from paddy soils. J. Microbiol., 36: $256-261$.

Crawford, R. L. and Mohn, W. W. 1985. Microbiological removal of pentachlorophenol from soil using a flavobacterium. Enzyme Microbial Technol., 7 (12): 617-620.

Cycon, M., Wójcik, M. and Piotrowska-Seget, Z. 2009. Biodegradation of the organophosphorus insecticide diazinon by Serratia sp. and Pseudomonas sp. and their use in bioremediation of contaminated soil. Chemosphere, 76: 494501.

Dai, Y. J., Chen, T., Ge, F., Huan, Y., Yuan, S. and Zhu, F. F. 2007. Enhanced hydroxylation of imidacloprid by Stenotrophomonas maltophiliaupon addition of sucrose. App. Microb. Biotech., 74: 995-1000.

Desaint, S., Hartmann, A., Parekh, N. R. and Fournier, J. C. 2000. Genetic diversity of carbofuran degrading soil bacteria. FEMS Microbiology Ecology, 34 (2): 173-180.

Diez, M. C. 2010. Biological aspects involved in the degradation of organic pollutants. J. Soil Sci. Plant Nutrition, 10 (3): 244-267.

Fang, H., Dong, B., Yan, H., Tang, F. and Yunlong, Y. 2010. Characterization of a bacterial strain capable of degrading DDT congeners and its use in bioremediation of contaminated soil. J. Hazard. Mater., 184(1-3): 281-289.

Forget, G. 1993. Balancing the need for pesticides with the risk to human health. In: Impact of pesticide use on health in developing countries by Eds. G. Forget G, Goodman T, de Villiers A. pp. 2-16.

Head, I. M., Cain, R. B. and Suett, D. L. 1992. Characterization of a carbofuran degrading bacterium and investigation of the role of plasmids in catabolism of the insecticide carbofuran. Archiv. Microbiol., 158 (4): 302-308.

Jauregui, J., Valderrama, B., Albores, A. and Vazquez-Duhalt, R. 2003. Microsomal transformation of organophosphorus pesticides by white rot fungi. Biodegradation, 14: 397-406.

Joosten, V. and Van Berkel, W. J. H. 2007. Flavoenzymes. Cur. Opinion in Chem. Biol., 11: 195-202.

Kamanavalli, C. M. and Ninnekar, H. Z. 2005. Biodegradation of DDT by a Pseudomonas species. Curr. Microbiol., 48 (1): 10-13.

Li, X., He, J. and Li, S. 2007. Isolation of chlorpyrifos degrading bacterium Sphingomonas sp. strain Dsp-2 and cloning of the mpd gene. Res. Microb., 158: 143-149.

Malghani, S., Chatterjee, N., Yu, H. X. and Luo, Z. 2009. Isolation and identification of profenofos degrading bacteria. Braz. J. Microbiol., 40 (4): 893-900.

Matsumura, F., Boush, G. M. and Tai, A. 1968. Breakdown of dieldrin in the soil by a microorganism. Nature, 219 (5157): 965967.

Ortega, N. O., Nitschke, M., Mouad, A. M., Landgraf, M. D., Rezende, M. O. O., Seleghim, M. H. R., Sette, L. D. and Porto, A. L. M. 2011. Isolation of Brazilian marine fungi capable of growing on DDD pesticide. Biodegradation, 22: 43-50.

Ortiz-Hernández, M. L., Quintero-Ramírez, R., Nava-Ocampo, A. A. and BelloRamírez, A. M. 2003. Study of the mechanism of Flavobacterium sp. for hydrolyzing organophosphate pesticides. Fund. Clinic. Pharma. 17 (6): 717-23.

Ortiz-Hernandez, M. L., Sánchez-Salinas, E., Dantán-González, E. and CastrejónGodínez, M. L. 2013. Pesticide biodegradation: mechanisms, genetics and strategies to enhance the process In: Biodegradation - Life of Science. InTech Publishing.

Pandey, J., Chauhan, A. and Jain, R. K. 2009. Integrative approaches for assessing the ecological sustainability of in situ bioremediation. FEMS Microbiology 
Reviews, 332: 324-375.

Pankaj, A. S., Gangola, S., Khati, P., Kumar, G. and Srivastava, A. 2016. Novel pathway of cypermethrin biodegradation in a Bacillus sp. strain SG2 isolated from cypermethrin contaminated agriculture field. 3 Biotech, 6: 45.

Parte, S. G., Mohekar, A. D. and Kharat, A. S. 2017. Microbial degradation of pesticide: A review. African J. Microbiol. Res. 11 (24): 992-1012.

Patil, K. C., Matsumura, F. and Boush, G. M. 1970. Degradation of Endrin, Aldrin and DDT by soil microorganisms. J. Appl. Microbiol., 19 (5): 879-881.

Pesce, S. F. and Wunderlin, D. A. 2004. Biodegradation of lindane by a native bacterial consortium isolated from contaminated river sediment. Int. Biodeterior. Biodegradation, 54 (4): 255260.

Pizzul, L., Castillo, M. P. and Stenstrom, J. 2009. Degradation of glyphosate and other pesticides by ligninolytic enzymes. Biodegradation, 20: 751- 759.

Prasad, T. V. 2014. Chemical control and toxicology: In Handbook of Entomology. New Vishal Publications, New Delhi, India. Pp. 254-255.

Qing, Z., Yang, L. and Huan, L. Y. 2006. Purification and characterization of a novel carbaryl hydrolase from Aspergillus niger PY168. FEMS Microbiology Letters, 228 (1): 39-44.

Rigas, F., Dritsa, V., Marchant, R., Papadopoulou, K., Avramides, E. J. and Hatzianestis, I. (2005). Biodegradation of lindane by Pleurotus ostreatusvia central composite design. Environ. Int. 31 (2): 191-196.

Sarkar, S., Seenivasan, S. and Premkumar, R. 2009. Biodegradation of propiconazole by Pseudomonas putida isolated from tea rhizosphere. Plant Soil Environ. 55 (5): 196-201.

Scott, C., Pandey, G., Hartley, C. J., Jackson,
C. J., Cheesman, M. J., Taylor, M. C., Pandey, R., Khurana, J. L., Teese, M., Coppin, C. W., Weir, K. M., Russell, R. J. and Oakeshott, J. G. 2008. The enzymatic basis for pesticide bioremediation. Indian J. Microbiol., 48: 65-79.

Sethunathan, N. and Yoshida, T. 1973. A Flavobacterium sp. that degrades diazinon and parathion. Canadian J. Microb., 19: 873-875.

Sharma, A., Khati, P. P., Gangola, S. and Kumar, G. 2016. Microbial degradation of pesticides for environmental cleanup: In: Bioremediation of industrial pollutants. Educationist Press, Write \& Print Publications H-13, Bali Nagar, New Delhi. Pp: 178-205.

Singh, B. K. and Walker, A. 2006. Microbial degradation of organophosphorus compounds. FEMS Microbiology Reviews, 30 (3): 428-471.

Singh, B. K., Walker, A., Alun, J., Morgan. W. and Wright, D. J. 2004. Biodegradation of Chlorpyrifos by Enterobacter Strain B14 and its use in bioremediation of contaminated soils. Appl. Environ. Microbiol., 70: 4855-4863.

Singh, J. and Singh, D. K. 2005. Dehydrogenase and phosphormonoesterase activities in groundnut (Arachis hypogaea L.) field after diazinon, imidacloprid and lindane treatments. Chemosphere, 60 (1): 32-42.

Singh, P. and Thakur, I. S. 2006. Colour removal of anaerobically treated pulp and paper mill effluent by microorganisms in two steps bioreactor. Bioresource Tech., 97: 218-223.

Spain, J. C. and Nishino, S. F. 1987. Degradation of 1,4-Dichlorobenzene by a Pseudomonas sp. Appl. Environ. Microbiol., 53 (5): 1010-1019.

Stanlake, G. J. and Finn, R. K. 1982. Isolation and characterization of $a$ pentachlorophenol degrading bacterium. Appl. Environ. Microbiol., 44 (6): 1421- 
1427.

Tewari, L., Saini, J. K. and Arti. 2012. Bioremediation of pesticides by microorganisms: General aspects and recent advances: In: Bioremediation of Pollutants. I.K. International Publishing House Pvt. Ltd., New Delhi. Pp: 25-49.

Tian, L. S. and Chen, F. 2012. Biological characteristics and degradation performance of a degrading strain. J. Yangzhou Univ., 33 (1): 86-90.

Tomasek, P. H. and Karns, J. S. 1989. Cloning of a carbofuran hydrolase gene from Achromobacter sp. strain WM111 and its expression in gram negative bacteria. J. Bacteriology, 171: 4038-4044.

Torres-Duarte, C., Roman, R., Tinoco, R. and Vazquez-Duhalt, R. 2009. Halogenated pesticide transformation by a laccase mediator system. Chemosphere, 77 (5): 687-692.

Van Eerd, L. L., Hoagland, R. E., Zablotowicz, R. M. and Hall, J. C. 2003. Pesticide metabolism in plants and microorganisms. Weed Science, 51 (4): 472-495.

Wedemeyer, G. 1967. Dechlorination of 1,1,1-Trichloro-2,2-bis(pchlorophenyl) ethane by Aerobacter aerogene. J. Appl. Microbiol., 15 (3): 569-574.

Weir, K. M., Sutherland, T. D., Horne, I., Russell, R. J. and Oakeshott, J. G. 2006. A single monooxygenase, ese, is involved in the metabolism of the organochlorides endosulfan and endosulfate in an Arthrobacter sp. App. Environ. Microb., 72 (5): 3524-3530.
Widada, J., Nojiri, H. and Omori, T. 2002. Recent developments in molecular techniques for identification and monitoring of xenobiotic-degrading bacteria and their catabolic genes in bioremediation. App. Microb. Biotech., 60: 45-59.

Wolf, C., Dalal, S., DaVanzo, J., Larson, E. V. Akhmedjonov, A. R., Dogo, H. Huang, M. and Montoya, S.2011. Population trends in China and India: demographic dividend or demographic drag?. RAND report, China and India, 2025: A Comparative Assessment, MG-1009- OSD Xiao, P., Mori, T., Kamei, I. and Kondo, R. 2010. Metabolism of organochlorine pesticide heptachlor and its metabolite heptachlor epoxide by white rot fungi, belonging to genus Phlebia. FEMS Microbiol. Lett., 314 (2): 140-146.

Ye, X., Dong, F. and Lei, X. 2018. Microbial resources and ecology - microbial degradation of pesticides. Natural Res. Conserv. Res. 7: 22-28.

Yuanfan, H., Jin, Z., Qing, H., Qian, W., Jiandong, J. and Shunpeng, L. 2010. Characterization of a fenpropathrin degrading strain and construction of a genetically engineered microorganism for simultaneous degradation of methyl parathion and fenpropathrin. J. Environ. Manage., 91: 2295-2300.

Zhongli, C., Shunpeng, L. and Guoping, F. 2001. Isolation of methyl parathion degrading strain M6 and cloning of the methyl parathion hydrolase gene. App.Environ. Microb., 59: 4922-4925.

\section{How to cite this article:}

Sudhansu Bhagawati, Badal Bhattacharyya, Snigdha Bhattacharjee, E. Bidyarani Devi, Nang Sena Manpoong and Partha Pratim Gyanudoy Das. 2020. Microbial Bioremediation of Pesticide Residues: A Review. Int.J.Curr.Microbiol.App.Sci. 9(04): 1551-1561. doi: https://doi.org/10.20546/ijcmas.2020.904.182 